\title{
Factors Contributing To Academic Dishonesty Among Nursing Students In Kenya Medical Training College Western Kenya
}

\author{
Emily M. W. Wamalwa, John M. Okoth, Damaris Ochanda
}

\begin{abstract}
Introduction: Academic integrity is important in training of nurses since on completion of their studies the nurses will be involved in taking care of lives. Academic dishonesty among nursing students leads to putting the lives of patients at risk. The Purpose of this study was toassess factors contributing to academic dishonesty among Nursing Students in Kenya Medical Training Colleges in Western Kenya.

Methodology: A cross-sectional analytical design was employed in this study. Qualitative data was collected from lecturers, administrators, examination coordinators, disciplinary committee chair persons using Key informant interviews. Structured questionnaires for students and available records were used to collect quantitative data. Three colleges were randomly sampled to include Webuye and Bungoma in Bungoma County, kakamega in Kakamega County. Systematic sampling was used to select222 students who participated in the study while purposive sampling was used in selecting $12 \mathrm{key}$ informants. Qualitative data collected addressed factors contributing to academic dishonest. Data entered in SPSS version 25 software and analysis done using both descriptive and inferential statistics. Odds ratio and $p$ value were used to determine the strength of association. A pvalue of less than or equal to 0.05 was considered significant.
\end{abstract}

Findings: The results revealed that of the 202 students, about $47 \%$ got involved in the academic malpractices of which most respondents were females. However, the study results did not reveal any relationship between respondents' sociodemographic characteristics (age, gender) and the acts of academic dishonesty although a higher proportion of females (48.6\%) and those aged 20 years and above $(49.5 \%)$ were involved. The study indicated that students were sensitized on academic dishonesty at the beginning of their program through various ways with students' handbook being used the commonest (40.1\%). Most common form of academic dishonesty students engaged in was cheating (71.6\%);most students gave fear of consequences as the most important reason that deterred them from engaging in academic malpractices at $20 \%$.Mainfactor contributing to academic dishonesty was the lack of lecturers to adhere to policies during administration of examinations (OR: $2.3 ; 95 \%$ CI: 1.2-4.5; 0.01). Other factors include students not aware of college rules (OR:0.6;95\% CI:0.3-1.0;0.07), overcrowding (47.8\%), accessibility to examination material $(\mathbf{4 8 . 5 \% )}$ ) and peer pressure $\mathbf{( 5 0 . 4 \% )}$.

Published on August 7, 2020

Emily M. W. Wamalwa, Masinde Muliro University of Science \& Technology, Kenya.

(corresponding e-mail: wamalwaemmy@gmail.com)

John M. Okoth, Masinde Muliro University of Science \& Technology, Kenya.

(e-mail: jokoth@mmust.ac.ke).

Damaris Ochanda, Masinde Muliro University of Science \& Technology, Kenya.

(e-mail: dochanda@mmust.ac.ke).
Conclusion: The study concludes that academic dishonesty is prevalent in the three colleges with cheating as the commonest form with various contributing factors namely: overcrowding and lack of lecturers adhering to policies in administration of examinations, followed by family pressure to perform well.

Recommendation: This study therefore recommends that lectures should adhere to college policies particularly during invigilation of examinations and the administration should ensure provision of enough spacing during examination. This will contribute immensely towards enhancing academic integrity among nursing students.

Index Terms - Academic; dishonesty; nursing; students.

\section{INTRODUCTION}

Academic dishonesty is the application of illegitimate aid with the intention of deceiving an instructor or other individuals that have been assigned the evaluation of students' work in meeting course requirements [28]. It is an old age issue for administrators and the faculty at large and has been the topic of ethical debate for many years [18]. There are many complex, moral, ethical, cultural and social issues revolved around academic dishonesty [14]. Since the founding of institutions of higher learning, academic dishonest has been rampant in fluctuating degrees, and this has been evidenced by Aristotle's influencing works on politics and ethics. The core of the Hippocratic Oath is a commitment to serve others diligently and to refrain from cheating [5]. Colonial schools and institutions of higher learning adhered to policies established for the purpose of ethical and moral conduct [10]. There is therefore, a need to uphold and be cautious on the global standards of acceptable scholarly behavior. Consequently, institutions should unite and establish policies and guidelines that have universal credibility and which will be globally more uniform and effective [18].

Academic dishonesty among students is a rising issue in higher education and middle colleges. Globally, above $80 \%$ of college students accept that cheating is essential to forge ahead in higher learning [19]. Over 70\% of all college students now confess to having engaged in different forms of academic dishonesty [6]. Students are expected to produce their independent work with acknowledgement of the sources from which they receive information [29]. Previous studies report that the explanations for student academic dishonesty are complex. Some of reasons as to why students engage in academic cheating include stressful environment, burden to perform well and acquire employment after graduation, peer competition and lack of preparation [26]. 
Research has shown that the frequency of academic dishonesty in colleges is above 70\% [6]. A survey done in South Korea in the year 2016, revealed that9,229 cases of academic dishonesty were reported in one year out of these 143 students were expelled with the average rate of plagiarism being $0.72 \%$ equivalent to 7 cases in every 1000 . Globally, above $80 \%$ of college students believe cheating is a necessity to excel [19]. Averages of $70 \%$ of students now confess to having engaged in different forms of academic dishonesty [6]. In Kenya about 50\% academic dishonesty cases occurs in most colleges with various forms being reported in the year 2012 and specific to western region, about $50 \%$ of students in higher institutions of learning admitted to have been involved in various types of academic dishonesty [6].

Kenya Medical Training College report for the years 2015/2016 showed that there was an upsurge of Academic Dishonesty in most Colleges nationwide. This is contrary to the expectation that students should be $100 \%$ honest in their work since their future career revolves around taking care oflives [6]. There is an urgent need for restoration and upholding of academic integrity among nursing students as this has adverse consequences which can adversely affect patients by graduating students who lack the required qualifications thus jeopardizing the quality of care provided to patients [11]. However, in western region of Kenya, there is little evidence of studies having been carried out as far as contributory factors of academic dishonesty are concerned. Therefore, this study aims at investigating Academic Dishonesty and single out its major contributing factors [28].

\section{Methodology}

A cross-sectional analytical design was employed in this study. Participating colleges were selected randomly from the rest of the colleges in Western region. Nursing students in all three colleges were selected using simple random sampling technique (Webuye, Busia and Kakamega) from 450 nursing students, other Staff respondents were selected purposively as follows principals, examination coordinators, disciplinary committee chairpersons and administrative officers. Qualitative data was collected from lecturers, administrators, examination coordinators, disciplinary committee chair persons using Key informant interview schedules. Structured questionnaires were administered to 202 students sampled systematically and available academic Existing college records and registers on prevalence and incidences of academic dishonesty were also accessed for quantitative data. Dataentered in SPSS version 25 software and analysis done using both descriptive and inferential statistics. Odds ratio and $\mathrm{p}$ value were used to determine the strength of association. A p-value of less than or equal to 0.05 was considered significant.

\section{FINDINGS}

\section{A. Socio demographic Characteristics of students}

Most respondents as shown in Table 1 were females 55\% $(n=111)$ while males comprised $45 \%(n=91)$. More than half,
$51.6 \%(n=97)$ of the respondents were above 20years followed by those below 18 years at $27.3 \%$ (40/202). Majority, (98.5\%) were Christians. Most of the students were in their second year at $44.1 \%$ followed by first years at $35.1 \%$.

\begin{tabular}{|c|c|c|c|}
\multicolumn{4}{|c|}{ TABLE 1: SOCIO DEMOGRAPHIC CHARACTERISTICS OF RESPONDENTS } \\
\hline Variable & Categories & $\mathbf{N}$ & $\mathbf{\%}$ \\
\hline \multirow{3}{*}{ Gender } & Male & 91 & 45.0 \\
\cline { 2 - 4 } & Female & 111 & 55.0 \\
\cline { 2 - 4 } & Total & $\mathbf{2 0 2}$ & $\mathbf{1 0 0}$ \\
\hline \multirow{3}{*}{$\begin{array}{c}\text { Age group in } \\
\text { years }\end{array}$} & $<18$ & 51 & 25.3 \\
\cline { 2 - 4 } & $18-20$ & 54 & 26.7 \\
\cline { 2 - 4 } & $>20$ & 97 & 48.0 \\
\cline { 2 - 4 } & Total & 202 & 100 \\
\hline \multirow{2}{*}{ Religion } & Christian & 199 & 98.5 \\
\cline { 2 - 4 } & Muslim/Others & 3 & 1.5 \\
\hline \multirow{3}{*}{ Year of study } & Total & $\mathbf{2 0 2}$ & $\mathbf{1 0 0}$ \\
\hline & Year 1 & 71 & 35.1 \\
\cline { 2 - 4 } & Year 2 & 89 & 44.1 \\
\cline { 2 - 4 } & Year 3 & 42 & $\mathbf{1 0 0}$ \\
\hline
\end{tabular}

\section{B. Prevalence and nature of academic dishonesty}

The findings revealed that of the 202 students, about 47 $\%$ got involved in academic malpractices of which most respondents were females. The one year reviewed academic disciplinary committee records revealed a prevalence of $42 \%$ of academic dishonesty in Kakamega MTC, $40 \%$ in Bungoma MTC and $18 \%$ in Webuye MTC.

Figure 1 presents nature of academic dishonesty categorised into specific forms. Findings show that cheating is leading (71.6\%) followed by plagiarism (13.7\%), collusion (8.4\%) and falsifying data (5.3\%). Other categories included clinical misconduct such as falsifying patients' records, at (1.1\%).

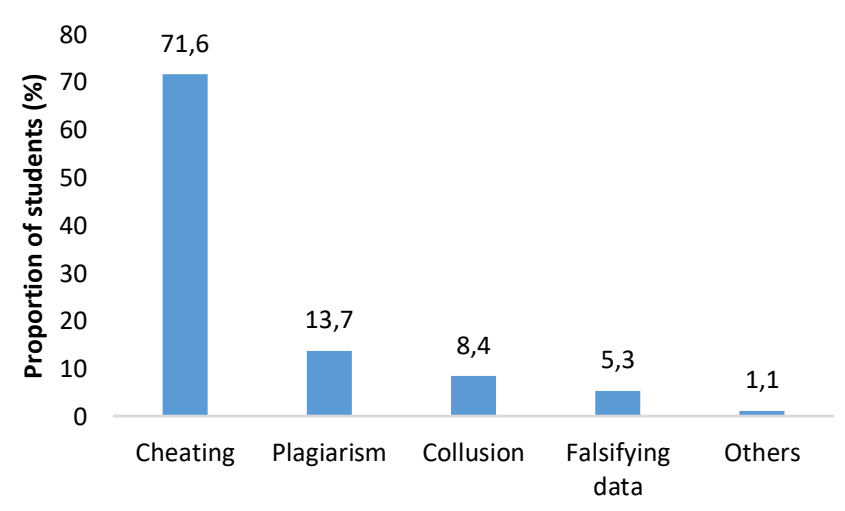

Fig. 1. Nature of academic dishonesty.

Findings from key informant interview (DCC1) support that cheating is the most common form of academic dishonesty:

'Most of our students are usually found with small notes in the examination room. A few would have with some writings on the palm of their hands while others being involved in clinical misconducts' (DCC 1).

\section{Source s of Information on academic Dishonesty}

Figure 2 shows that the main source of information for the students on academic dishonesty in the three colleges was students' handbook issued to them at the beginning of training at $40.1 \%$, while lecturers comprised $23.8 \%$ and 
school website $11.4 \%$. Among the respondents, $11.9 \%$ never got any information on academic dishonesty and only $5.4 \%$ got the information during orientation. This is contrary to what one of the key informants stated:

'It is mandatory that all students are given orientation at the beginning of their training which includes pointing out on the dire consequences of academic dishonesty. It is against college policies for any lecturer to deny students such an opportunity as it can compromise quality of education and care' (Principal 3).

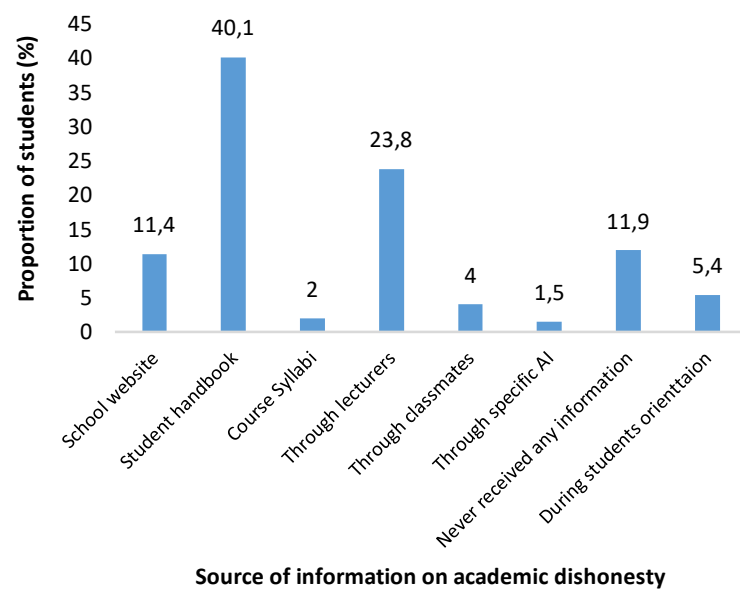

Fig. 2. Sources of information on academic dishonesty.

\section{Reasons for not cheating}

As shown in Figure 1.3 main reasons for not cheating among the respondents included fear of consequences (20\%), personal evaluation on whether learning took place (19.1\%), personal/ethical code (19.1\%) and respect for faculty $(19 \%)$. This was also supported by findings from key informant DCC3.

'Many students fear dire consequences. Once one of them is found cheating, the punishment applied to him/her is usually heavy which scares most of them; this has seen a decline in academic malpractices in our college' (DCC 3).

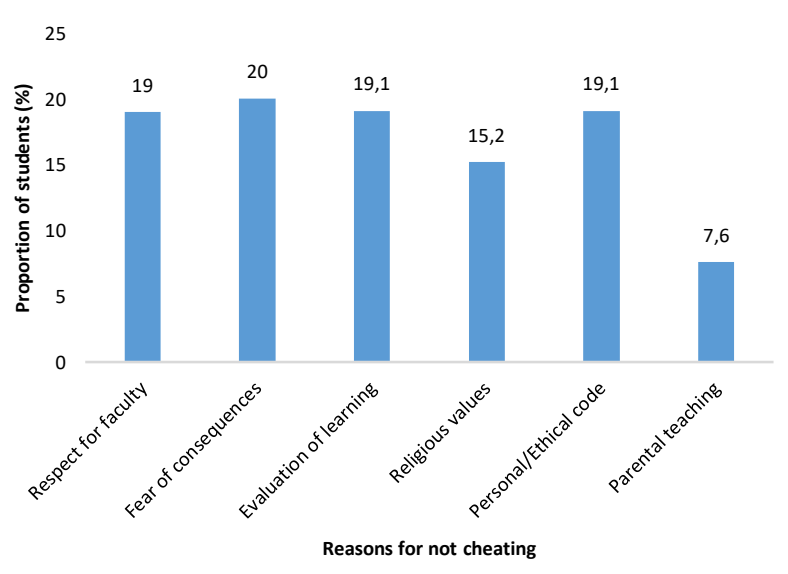

Fig. 3. Reasons for not cheating.

\section{E. Socio-demographic factors contributing to academic dishonesty}

Table 2 shows results on bivariate analysis on the association between student socio-demographic characteristics and academic dishonesty. None of the sociodemographic variables was statistically significantly associated with academic dishonesty. However, findings reveal interesting outcomes. A higher proportion of students aged 20 years and above (49.5\%) compared to $44.3 \%$ of the younger age group were involved in academic dishonesty. Likewise, more second years $(52.8 \%)$ than the rest of the other students in year one and three $(42.5 \%)$ participated in the malpractice.

Results from key informants equally confirmed that student' socio-demographic variables do not influence involvement in academic dishonesty:

'Students cheat in academics regardless of age, gender and year of study. Every student wants to pass examination and given chance they can do what it takes to pass.' (Exam Coordinator 1).

TABLE 2: STUDENTS' SOCIO-DEMOGRAPHIC FACTORS ASSOCIATED WITH ACADEMIC DISHONESTY

\begin{tabular}{|c|c|c|c|c|c|c|c|}
\hline \multirow[t]{2}{*}{ Variable } & \multirow[t]{2}{*}{ Categories } & \multirow[t]{2}{*}{$\mathrm{n}$} & \multicolumn{2}{|c|}{$\begin{array}{l}\text { Involvement } \\
\text { in academic } \\
\text { dishonesty }\end{array}$} & \multirow[t]{2}{*}{ OR } & \multirow[t]{2}{*}{$95 \% \mathrm{CI}$} & \multirow{2}{*}{$\begin{array}{c}\mathrm{p} \\
\text { value }\end{array}$} \\
\hline & & & $\begin{array}{l}\text { Yes } \\
(\%)\end{array}$ & $\begin{array}{l}\text { No } \\
(\%)\end{array}$ & & & \\
\hline \multirow[t]{2}{*}{ Gender } & Male & 91 & 45.0 & 55.0 & \multirow[t]{2}{*}{0.9} & \multirow[t]{2}{*}{$0.5-1.5$} & \multirow[t]{2}{*}{0.6} \\
\hline & Female & 111 & 48.6 & 51.4 & & & \\
\hline \multirow{2}{*}{$\begin{array}{l}\text { Age } \\
\text { group in } \\
\text { years }\end{array}$} & $<20$ & 97 & 44.3 & 55.7 & \multirow[t]{2}{*}{0.8} & \multirow[t]{2}{*}{$0.5-1.4$} & \multirow[t]{2}{*}{0.5} \\
\hline & $\geq 20$ & 105 & 49.5 & 50.5 & & & \\
\hline \multirow{2}{*}{$\begin{array}{l}\text { Year of } \\
\text { study }\end{array}$} & Year 2 & 89 & 52.8 & 47.2 & \multirow[t]{2}{*}{1.5} & \multirow[t]{2}{*}{$0.9-2.6$} & \multirow[t]{2}{*}{0.1} \\
\hline & Year 1/3 & 113 & 42.5 & 57.5 & & & \\
\hline
\end{tabular}

F. Influence of student's awareness on academic dishonesty and involvement in the malpractice

Table 3 presents bivariate analysis on students' awareness and involvement in academic dishonesty. Results suggest that students who were aware of cheating being the commonest form of academic dishonesty were almost twice as likely to commit academic dishonesty compared to those who were aware of other forms of malpractice (OR:1.8;95\%CI:1.0-3.4: $\mathrm{p}=0.06$ ) although the result was marginally statistically significant. Furthermore, a higher proportion of students who rated academic dishonesty as 'high' (53.1\%) were involved in the malpractice as compared to $44.2 \%$ who were not. The results could be corroborated by what one of the key informants stated below:

'We use our own intelligence to single out those involved and once proved guilty we punish them thoroughly to deter others from the acts. Students are aware of the consequences. Students rarely report their colleagues who get involved in academic dishonesty.' (Principal, 3)

\section{G. Perceived factors contributing to academic dishonesty}

Table 4 shows results of bivariate analysis on the causes of academic dishonesty. Available evidence showed that students who agreed with lack of lecturers adhering to policies as a probable cause of academic dishonesty were two times more likely to have committed academic malpractice (OR: 2.3 ; 95\%CI: $1.2-4.5$; 0.01).A marginally statistically significantly proportion of students who were not aware of ineffective college rules against malpractice were likely to have been involved in academic malpractice 
(OR: $0.6 ; 95 \%$ CI: $0.3-1.0 ; 0.07$ ). Forty percent of the former group were less likely to have participated in the malpractice.

TABLE 3: RELATIONSHIP BETWEEN STUDENT'S AWARENESS ON ACADEMIC DISHONESTY AND INVOLVEMENT IN MALPRACTICE

\begin{tabular}{|c|c|c|c|c|c|c|c|}
\hline \multirow[t]{2}{*}{ Variable } & \multirow[t]{2}{*}{ Categories } & \multirow[t]{2}{*}{$\mathrm{N}$} & \multicolumn{2}{|c|}{$\begin{array}{c}\text { Involvement in academic } \\
\text { dishonesty }\end{array}$} & \multirow[t]{2}{*}{ OR } & \multirow[t]{2}{*}{$95 \% \mathrm{CI}$} & \multirow[t]{2}{*}{$\mathrm{p}$ value } \\
\hline & & & Yes (\%) & No $(\%)$ & & & \\
\hline \multirow{2}{*}{$\begin{array}{l}\text { Rating of academic } \\
\text { dishonesty }\end{array}$} & High & 64 & 53.1 & 46.9 & \multirow{2}{*}{1.4} & \multirow{2}{*}{$0.8-2.6$} & \multirow{2}{*}{0.2} \\
\hline & Low & 138 & 44.2 & 55.8 & & & \\
\hline \multirow{2}{*}{$\begin{array}{l}\text { Commonest nature of } \\
\text { academic dishonesty }\end{array}$} & Cheating & 142 & 51.4 & 48.6 & \multirow{2}{*}{1.8} & \multirow{2}{*}{$1.0-3.4$} & \multirow{2}{*}{0.06} \\
\hline & Other forms & 60 & 36.7 & 63.3 & & & \\
\hline \multirow{2}{*}{$\begin{array}{l}\text { Students report incidences } \\
\text { of academic dishonesty }\end{array}$} & Yes & 103 & 45.6 & 54.4 & \multirow{2}{*}{0.9} & \multirow{2}{*}{$0.5-1.6$} & \multirow{2}{*}{0.7} \\
\hline & No & 99 & 48.5 & 51.5 & & & \\
\hline \multirow{2}{*}{$\begin{array}{l}\text { School administration } \\
\text { aware of exam } \\
\text { malpractices }\end{array}$} & Yes & 139 & 43.2 & 56.8 & \multirow{2}{*}{0.6} & \multirow{2}{*}{$0.3-1.1$} & \multirow{2}{*}{0.1} \\
\hline & No & 63 & 55.6 & 44.4 & & & \\
\hline
\end{tabular}

Other results that are important includes overcrowding (49.7\%), students being main contributors (49.4\%), family pressure $(47.8 \%)$, accessibility to exam materials $(48.5 \%)$, lack of self-confidence $(47.8 \%)$ and peer pressure $(50.4 \%)$ with most of the students who perceived these as the major causes, having been involved in the malpractice. However, the results were non-statistically significant.

'Some come in as very hard working and loyal students but get influenced by their friends who may be dishonest. Most students don't study hard, they lazy around hoping to cheat during examination period.' (DCC 2).

TABLE 4: PERCEIVED FACTORS CONTRIBUTING TO ACADEMIC DISHONESTY

\begin{tabular}{|c|c|c|c|c|c|c|c|}
\hline \multirow{2}{*}{$\begin{array}{c}\text { Causes of academic } \\
\text { dishonesty }\end{array}$} & \multirow{2}{*}{ Categories } & \multirow{2}{*}{$\mathrm{n}$} & \multicolumn{2}{|c|}{$\begin{array}{c}\text { Involvement in academic } \\
\text { dishonesty }\end{array}$} & \multirow{2}{*}{ OR } & \multirow{2}{*}{$95 \% \mathrm{CI}$} & \multirow{2}{*}{$P$ value } \\
\hline & & & Yes $(\%)$ & $\begin{array}{l}\text { No } \\
(\%)\end{array}$ & & & \\
\hline \multirow[t]{2}{*}{ Overcrowding } & Agree & 165 & 49.7 & 50.3 & \multirow{2}{*}{1.8} & \multirow[b]{2}{*}{$0.8-3.8$} & \multirow{2}{*}{0.1} \\
\hline & Disagree & 37 & 35.1 & 64.9 & & & \\
\hline \multirow{2}{*}{$\begin{array}{l}\text { Conducive environment that } \\
\text { supports academic integrity }\end{array}$} & Agree & 164 & 47.0 & 53.0 & \multirow{2}{*}{1.0} & \multirow{2}{*}{$0.5-2.0$} & \multirow{2}{*}{0.9} \\
\hline & Disagree & 38 & 47.4 & 52.6 & & & \\
\hline \multirow[t]{2}{*}{ Main contributors } & Students & 162 & 49.4 & 50.6 & \multirow{2}{*}{1.6} & \multirow{2}{*}{$0.8-3.3$} & \multirow{2}{*}{0.2} \\
\hline & Others & 40 & 37.5 & 62.5 & & & \\
\hline \multirow{2}{*}{$\begin{array}{l}\text { Overcrowding and Lack of } \\
\text { Lecturers adhering to } \\
\text { policies in administration of } \\
\text { examinations }\end{array}$} & Agree & 152 & 52.0 & 48.0 & \multirow[b]{2}{*}{2.3} & \multirow[b]{2}{*}{$1.2-4.5$} & \multirow[b]{2}{*}{0.01} \\
\hline & Disagree & 50 & 32.0 & 68.0 & & & \\
\hline \multirow[t]{2}{*}{ Cheating for better results } & Agree & 107 & 47.1 & 52.9 & \multirow{2}{*}{1.0} & \multirow{2}{*}{$0.6-1.7$} & \multirow{2}{*}{0.9} \\
\hline & Disagree & 95 & 47.4 & 52.6 & & & \\
\hline \multirow[t]{2}{*}{ Family pressure } & Agree & 163 & 47.8 & 52.2 & \multirow{2}{*}{1.2} & \multirow{2}{*}{$0.5-2.6$} & \multirow{2}{*}{0.06} \\
\hline & Disagree & 39 & 43.3 & 56.7 & & & \\
\hline \multirow{2}{*}{$\begin{array}{l}\text { Accessibility to exam } \\
\text { materials on net }\end{array}$} & Agree & 134 & 48.5 & 51.5 & 00 & $06 \quad 21$ & 06 \\
\hline & Disagree & 68 & 45.5 & 55.0 & 0.9 & $0.6-2.1$ & 0.6 \\
\hline Laziness among students & Agree & 136 & 49.3 & 50.7 & 11 & $06-20$ & 007 \\
\hline & Disagree & 66 & 47.2 & 52.8 & 1.1 & $0.0-2.0$ & 0.07 \\
\hline Unaware of college rules & Agree & 126 & 42.1 & 57.9 & 06 & $03-10$ & 07 \\
\hline & Disagree & 72 & 55.6 & 44.4 & 0.6 & $0.3-1.0$ & 0.7 \\
\hline Lack of self-4confidence & Agree & 134 & 47.8 & 52.2 & 11 & $06 \quad 21$ & 07 \\
\hline & Disagree & 68 & 44.4 & 55.6 & 1.1 & $0.6-2.1$ & 0.7 \\
\hline Peer pressure & Agree & 119 & 50.4 & 49.6 & 14 & $08 \quad 25$ & ? \\
\hline & Disagree & 81 & 42.0 & 58.0 & 1.4 & $0.8-2.5$ & 0.2 \\
\hline In order to improve college & Agree & 122 & 48.4 & 51.6 & & 0620 & 006 \\
\hline ranking. & Disagree & 80 & 45.0 & 55.0 & 1.1 & $0.6-2.0$ & 0.06 \\
\hline
\end{tabular}

\section{Discussion}

The findings results revealed that of the 202 students, about $47 \%$ got involved in academic malpractices of which most respondents were females. However, the study results did not reveal any relationship between respondents' sociodemographic characteristics (age, gender) and the acts of academic dishonesty. This is contrary to a study conducted by [36] which suggested that gender differences and age were associated with academic malpractice.

Contributory factors to academic dishonesty included overcrowding and lack of lecturers adhering to policies in administration of examination. Other important causes though not statistically significant were family pressure to perform well. A similar study carried out in New York revealed that increased pressure to perform well from family and friends was seen as a risk in involvement in academic dishonesty acts [22]. This was a true reflection of a study done in Australia which pointed out that laxity on the side of lecturers during invigilation, pressure for better results and prior accessibility to examination materials were among causes of academic malpractices [34].

This study also highlighted that students in nursing colleges receive information about academic dishonesty through different methods at the beginning of their training 
which included student's handbook as the major way used to sensitize students. This is supported by [35] who confirmed that before commencement of training, it was important that students passed through specific training to help minimize acts of academic dishonesty. The study further pointed out reasons that made students not to get involved in academic practices which included fear of consequences as the major deterrent, personal evaluation of learning, personal/ ethical codes and respect for faculty. This corroborated with a similar study done in Malaysia which pointed out that most students found carrying out academic dishonesty acts were heavily fined and this scared their colleagues who had plans to cheat in examinations and assignments [33].

This study found that the commonest form of academic dishonesty is cheating which is supported by [33] whose study in Australia revealed that majority of students cheated by carrying small notes into the examination room.

\section{CONCLUSIONS AND RECOMMENDATIONS}

Involvement in academic dishonesty in Kenya Medical Training Colleges among nursing students is prevalent with cheating as the commonest. The common contributory factors are overcrowding, lack of lecturers adhering to examination rules, regulations and policies during administration of examinations and pressure to perform well. Student's orientation and availability of student hand book are the main sources of information on academic dishonesty. This study recommends the management of Medical Training Colleges to address space issues to avoid overcrowding during examination and examiners to abide by policies and regulations during exam administration. Orientation of students and use of student handbooks will inculcate discipline and improve academic integrity among nursing student.

\section{ACKNOWLEDGMENT}

I want to appreciate my supervisors Prof. Lt. Col (Rtd) John M. Okoth and Dr. Damaris Ochanda for their timely and untiring support always whenever I needed their help in the production of this document. I appreciate also Mr. John Arudo for his guidance not forgetting friends, my children (Thomas and Wilson Peter), and my workmates for support and encouragement throughout the process of production of this document.

\section{REFERENCES}

[1] Boston University School of Public Health report, (2013). Confounding factors influencing academic integrity.

[2] Bowers (1964). Effects of social pressure on students for good grades.

[3] Bretag, T., \& Harper. (2017) addressing contract cheating: Local and global responses. Project on contract cheating and assessment Design.

[4] Brimble, M. (2016) Why students cheat; an exploration of motivatirs of student academic dishonesty in higher education.

[5] Burnus, R, T., Graham, J.E., \& Walker, M. (2011). Are my colleagues soft on academic crime? Journal of Economics and Economic Education Research, 12(3), 55-64.Retieved July 29, 2015 from https://www.questia.com/library/journal/1G1-274409744/are-mycolleagues-soft-on-academiccrime.

[6] Centre for Academic Integrity (2012). About us. Retrieved from cheating. Explanation, responses and strategies. The journal of Higher Education, 77(5), 839-860. Retrieved July 29, 2015 from http://www.eacfaculty.org/pchideffer/Eng 102f/plagiarism/organizatio nal theory and student cheating.pdf.
[7] Coren, A. (2012). The theory of planned behaviour: will faculty confront students who cheat? Journal of Academic Ethics,10(3),171184-Retrieved October 28,2015 from http://dx.doi.org/10.1007/S10805-012-9162-7.

[8] Gallant, T. B. (2008). Academic integrity in the twenty first century: A teaching and Learning imperative. ASHE, Higher Education Report, 33(5), 1143. (EJ91635). Retrieved October 28,2015, from http://eric.ed.org/id=EJ791635.

[9] Gallant, T. B, \& Drinan, P. (2006). Organizational theory and student Hamlin, A., Barczk, C., Powell, G., \& Frost, J. (2013). A comparison of University efforts to contain academic dishonesty. Journal of legal, ethical and regulatory issues, 16(1), 35-46. Retrieved July 29,2015 fromhttp://www.read periodicals.com/201301/300195141.html.

[10] Hamlin, A., \& Powell, G. (2008). Academic dishonesty at southern Utah University: Policies, procedures and experiences in the school of business. Journal of the academy of business administration.

[11] Hensley, L. (2013). To cheat or not to cheat: A review with implications for practice. The community college enterprise, 19(2), 22-34 'Retrieved July 29, 2015, from https://www.questia.com/library/journal/1g1-3559387581 to cheat-ornot-to-cheat-a-review-with-implication.

[12] Huang, C-L. Yang, S. C \& Chen, A-S (2015). The relationships among students' achievement goals, willingness to report academic dishonesty and engaging in academic dishonesty social behaviour and personality. An international Journal, 43(1), 27-37. doi:10.2224/sbp.2015.43.1.27. Retrieved may 30, 2017, from https://www.sbp.journal.com/index.pup/sbp/article/view/13 634 .

[13] Hulsart, R, \& McCarthy, V (2009). Educator's role in promoting academicintegrity,10. Academic of educational leadership journal, 13(4), 49-60. Retrieved July 29, 2015, from http://www.glasscastle.com/clients/www-nocheating-org/adcouncil/research/cheating fact sheet.html.

[14] Jones, D. L R. (2011). Academic dishonesty: Are more students cheating? Business Communication quarterly, volume 74, number2, June 2011.141-150. Retrieved on July 13, 2017 from https: debdavis.pbworks.com.

[15] Josien, L., \& Broderick, B. (2013). Cheating in higher education: The case of multi-methods cheaters. Academy of Educational Leadership Journal, 17(3), 93-105.

[16] Kitahara, R., Westfall, F., \& Mankelwicz, J. New, multi-faceted hybrid approaches to ensuring academic integrity. Journal of Academic and Business Ethics, Retrieved from http://www.aabri.com/ manuscripts/10480.pdf, 2011.

[17] Lang, J. M (2013). Classroom practice. Are teachers creating classroom cheats? Times educational supplement,30(5059).23-32. Retrieved July, 29, 2015 from https://www.tes.com/articleaspx?story code $=6352762$.

[18] McCabe, D-L, Trevino, L. K \& Butterfield, K. D. (2001). Cheating in academic: A Decade of Research, Ethics \& Behavior 11(3).

[19] Mckibban, A. R \& Burdsal, C, A (2-13), Academic dishonesty, an in depth investigation ofassessing measurable constructs and a call for consistency in scholarship journal of academic Ethics 11(3),185 197.Retrieved October 28,2015 fromhttp://doi.org/10.1007/S10805013-9187-6.

[20] Mcmillan, J. H \& Schumacher, S. (2010). Researchineducation: Evidence-based inquiry (7thed.). Boston: Pearson Education.

[21] Method scheaters. Academy of educational leadership journal,17(2),93-105. Retrieved July 29, 2015, from, From https://www.questia.com/library/journal/ip3-2999118601/cheating-inhigher education-the-case-of -multi-methods.

[22] Morris, E. J., \& Carroll, J. (2016) Academic Integrity: A teaching and learning approach in developing a sustainable holistic institutional approach.

[23] Nahirams Aslam (2010). Topology of reasons for students cheating. Boston.

[24] Newstead, Franklin-Stokes \& Armstead (1996). Studies in correlation between grade point average and frequency of cheating.

[25] Newton, P. M. (2016). Academic integrity: A qualitative study of confidence and Understanding in students at the start of their higher education. Assessment\&Evaluation in higher Education,41(3). 482 497. doi:10.1080/02602938.2015.1024199. Retrieved may30, 2017 from

https://cronfa.swan.ac.Uk/record/cronfa20205/Download/002020517042015081413.pdf.

[26] Academic dishonesty among higher institutions of learning. (Finn\&Frone, 2004).

[27] Sub Saharan contributory factors to academic dishonesty Ellis, Zucker\& Randall, 2018).

[28] (Nurses code of ethics handbook; 2008). Professional conduct of nurses at work place. 
[29] Novotney, A. (2011). Beat the cheat. Monitor on psychology, 42(6),
54 , Retrieved
July
29 ,
2015 ,

http://www.apa.org/monitor/2011/06/cheat.aspx.

[30] Olfason, L., Schraw, G., \& Kerwald, N. (2014). Academic dishonesty: Behaviours, Sanctio ns and retention of adjudicated college student development,55(7), 661-674. doi:10.1353/csd.2014.0066.

[31] Open Education Database (2010). Astonishing stats on academic cheating. Houston, Tx: oedb.org. Retrieved July 29, 2015, from http://oedb.org/ilibrarian/astonishing-stats-on-academic-cheating.

[32] Owunwanne, D., Rustagi, N., \& Dada, R. (2010). Students' perceptions of cheating and plagiarism in higher institutions, Journal of college teaching and learning, 7(11), 59-68. doi:1019030/tlc.v7:11.253. Retrieved may30, 2017, from https://www.chiteinstitute.com/jos/index.php/tlc/article/download/253 $/ 243$.

[33] Ellis,Zucker \& Randall(2018),Strategies in curbing academic dishonesty in African students.

[34] Harper and Mahmud, (2017), Probable causes of academic malpractices.

[35] Kitahara, R, Westfall, F. \& Mankelwicz, J. (2011). New multimedia faceted hybrid.

[36] Cole, M. T., Swartz, L. B., \& Shelley, D. J. (2014). Students 'use of technology in learning course material: Is it cheating? International Journal of information and communication Technology Education (IJICTE).10(1),35 48.doi:10.4818/ijicte.2014010104. 